\title{
Los gitanos españoles desde su salida de la India hasta los primeros conflictos en la península
}

\author{
M. ${ }^{a}$ Helena Sánchez Ortega *
}

\section{LOS GITANOS, DESDE SU SALIDA DE LA INDIA HASTA SU LLEGADA A EUROPA}

La personalidad histórica de los gitanos fue un enigma hasta el siglo XVIII. Historiadores, linguistas y viajeros se preguntaban acerca de su origen, características de su lengua, etc., to que es probable que contribuyera a formar en torno a ellos una aureola romántica. Hasta el último cuarto del siglo XVIII no establecieron Grellman, Rüdiger y Bryant, de forma casi simultánea, el origen indio de su lengua y, por tanto, de su etnia, pero todavía a principios del siglo xx continuaban discutiendo los estudiosos acerca del "puesto" exacto que corresponde a los gitanos en la familia indoaria. La mayor parte de los trabajos fiables correspondian, por tanto, a los especialistas en linguística, y todavía sigue siendo preciso referirse a este tipo de estudios cuando se quiere trazar el mapa de los desplazamientos del grupo gitano desde su salida de la India, en fechas no bien delimitadas.'

De acuerdo con un estupendo artículo de J. Sampson ${ }^{2}$ no pueden ser aceptados como primera referencia acerca de los gitanos después de su salida de la India los relatos legendarios a propósito de un grupo de

* UNED. Madrid.

Algunos estudiosos, entusiastas de la causa gitana, remontan la llegada de los gitanos a Europa a fechas muy tempranas. Bataillard suponia que hubo gitanos en la Grecia de Herodoto. e incluso de Homero, a pesar de lo cual reconocia la necesidad de limitarse a los estrictos datos históricos, según lo llevó a cabo él mismo al recoger las pruebas de la aparición en las distintas ciudades Europeas del siglo xv.

2 Dr. SAMPSON, John, "On the origin and early migration of the gypsies", Journal of the Gypsy Lore Society. Third series. Volum II, part 4. 
bailarines y músicos que llegaron a Persia en tiempos del rey sasánida Bahram Gur, y a los que se refiere el poeta persa Firdusi con el nombre de luris ${ }^{3}$. De acuerdo con Sampson, resulta más plausible relacionar a los gitanos con grupos que todavía pueden encontrarse en el Norte y Noroeste de la India. Colocan sus tiendas miserables en las afueras de los poblados y fabrican cestas, y otros utensilios semejantes. En otras palabras, son miembros de la casta inferior que trabajan como herreros y músicos ${ }^{4}$.

3 BLOCH J. recoge en su libro Los gitanos - Buenos Aires, editorial Universitaria, 1962, el texto del poeta Firdusi, indudablemente seductor. Según este relato, contenido en el Libro de los Reyes (terminado hacia 1011) fueron cedidos hacia 420 a.C. por el rey Sankal de Canogia a su yerno Bahram Gur, durante una etapa de su vida en que sólo aspiraba a la felicidad del pueblo. Había comprobado que una generosidad excesiva en materia de impuestos sólo servía para difundir la inmoralidad, y buscó otros medios para conseguir su objetivo:

"Más tarde escribió una carta a cada 'mobed' y, con el propósito de mejorar la condición de los pobres, les preguntó ¿quienes, en cada lugar, pueden vivir sin fatigas, y quienes son pobres y carentes de riquezas...". Recibió de cada "mobed" esta respuesta: "Vemos que la prosperidad es general y de todas partes se elevan continuas bendiciones. Los pobres, sin embargo, se lamentan de su infortunio y se quejan del rey, pues los ricos, coronados de flores, beben vino al son de músicas, mientras menosprecian a los hombres pobres que, como nosotros, beben sin música ni flores..." El rey se rió mucho al leer estas cartas y luego, en su veloz dromedario envió un mensajero a Schenguil, ordenándole que le dijera: "Oh-rey! misericordioso: escoge diez mil luris, hombres y mujeres, expertos tañedores de laud. Cuando estos llegaron el rey mando hacerlos comparecer, dió a cada uno un buey y un asno, pues quería de ellos hacer agricultores, e hizo que les entregaran mil cargas de trigo, ya que debian cultivar la tierra con sus bueyes y asnos, emplear el trigo para la siembra, recoger las cosechas y brindar a los pobres, gratuitamente, la música de sus instrumentos.

Los luris partieron, se comieron los bueyes y el trigo, y luego, al cabo de un año, tornaron a presentarse ante el rey con rostros macilentos. El rey les dijo: no debisteis derrochar las semillas, el trigo tierno, y la cosecha. Ahora os quedan vuestros asnos; cargadios con vuestras cosas, preparad los instrumentos musicales, y ponedles cuerdas de seda.

Todavia hoy, los luris, de acuerdo con las justas palabras del rey, andan por el mundo ganándose la vida compartiendo el albergue de perros y lobos, siempre dispuestos a robar en los caminos día y nochem.

"El libro de los Reyes" traducido por J. Mohl, VI, 1877, pág. 60. Medio siglo antes que Firdusi; el historiador árabe Hamzamh de ispahan contaba la misma historia, sólo que se trataba de individuos del pueblo "zott" y llegaban al número de doce mil. Los zott aparecen en el siglo vII como desertores del ejército persa. Se convirtieron al islamismo y se establecieron en Basora (BOLCH, J., ob. cit.)

A propósito de los luris y zott dice Sampson en su articulo citado «Impossible as it is to accept this legend as historical fact, it shows cleraly that there had been an Indian minstrel element in Persian know as Zott or Luri, at the time where Hamza and Firdusi wrote, and for a considerable period before. If we allow some fifty or sixty years for this tradition to have won general acceptance (as the Egyptian myth did later in mediaeval Europe) we may date the entry of the Gypsies into Persia about the end of the nintl century".

"Sampson señala lo siguiente a propósito de los “doms". The doms of Modern India, who exist as vagrant tribes, chiefly in Behar and in the West and North-West Provincies, have many features in common with the Gypsies. Bands of this people wander restlesly about with little ragged reed tents with tehy pitchcaoutside villages and strike again with marvellous rapidity after having despoiled the inhabitants. Some make baskests, mats and similar articles. In Dardistan, where they form a considerable part of the population and as elsewhere constitute the lower cast they are musicians, smiths, and leatherworkers" ("On the oriogin and early migration..."). 
Cualesquiera que sea su origen, los gitanos abandonaron la India como un grupo nómada que se instaló en Persia en fechas indeterminadas. De acuerdo con los análisis linguísticos de Sampson, en este área vivieron el tiempo suficiente para que su lengua se impregnara de bastantes elementos semíticos. Abandonaron Persia antes de la conquista árabe, y a partir de este momento, se dividen en dos familias diferentes que irán a instalarse en Siria y Armenia. Es posible que su estancia en Armenia fuera más breve que en Persia, pero también aquí permanecieron lo suficiente como para adquirir nuevos elementos que han podido ser estudiados por los especialistas. Probablemente; la inestabilidad interior del país, sometida a frecuentes ataques por parte de los soldados bizantinos en el siglo $\mathrm{xI}$, les obligó de nuevo a buscar un nuevo hogar, y a continuación podemos seguir las huellas de su paso por la Grecia bizantina. Nuevos vocablos se incorporan a la lengua de los gitanos, y gracias a ellos resulta posible señalar que debieron llegar hasta este nuevo asentamiento antes del final del siglo $\mathrm{xl}$, donde encontramos por primera vez testimonios históricos más seguros que las leyendas acerca de los luris. Un monje del monte Athos que escribía alrededor del año 1100 se refiere a un grupo de hombres descendientes de la raza samaritana de Simón Mago, que eran brujos famosos e incluso aficionados a envenenar animales. Un siglo más tarde se hablará de ellos como encantadores de serpientes y adivinadores del porvenir. En 1322 Simon Simeonis les describe en su Itinerarium durante su paso por Creta, considerándoles como a gentes que aseguraban descender de la familia de Ham. Según Simon Simeonis, nunca se paraban en un lugar más de treinta días, yendo de lugar en lugar con sus tiendas, 10 mismo que los árabes ${ }^{5}$. Por estas mismas fechas, aparecen también como vasallos en Corfú y siervos en Valaquia. Según Sampson, antes de fines del siglo Xiv los gitanos ya se habian extendido por la zona balcánica.

Después de su llegada a Europa empezamos a contar con cierta abundancia de datos para fechar con exactitud su presencia en los distintos países. Presionados por la invasión de los turcos, los gitanos deciden explorar Europa Occidental a partir de 1417 y viajan con suma rapidez. Hamburgo y otras ciudades hanseáticas el mismo año. Leipzig, Frankfurt, Suiza y Bavaria en 1418, Francia y la Provenza en 1419, Flandes en 1420 , Bolonia y Roma en 1422.

De acuerdo con el profesor Batallairad, quien se ocupó a fines del siglo pasado de la llegada a Europa de los gitanos durante este período

5 Citado por SAMPSON, art. cit. cltinerarium Symone Simeonis et Hugonis Illuminatore ad Terram Sanctam", pág. 17. 
en una serie de artículos que me parece oportuno recordar ahora ${ }^{6}, 1417$ puede ser considerada como la fecha que señala la aparición oficial de nuestra minoría en Europa. Bataillard se refiere al hecho de que los líderes, que se autodenominaban "condes", "duques" y otros títulos similares, se presentaron con cartas de recomendación del Emperador de Alemania y el propio Papa -en 1422- Los “condes» y «duques» aseguraban que eran peregrinos del camino hacia lugares santos donde tenían que purgar el pecado de apostasía que habían cometido al abjurar de sus creencias cristianas bajo la presión de los musulmanes. Según Bataillard, los jefes de las diferentes agrupaciones que irrumpen por estas fechas en casi todas las capitales europeas se mantenían en contacto entre sí, y estaban realizando la exploración del territorio en el que pensaban asentarse a continuación.

En 1418 llegan a Augsburgo unos 50 gitanos, seguidos por un gran número de mujeres y chiquillos. Aseguraron que provenían de la Pequeña Egipto y que eran expertos en el arte de la adivinación. La crónica que da cuenta de su llegada los presenta también como expertos en el pequeño robo ${ }^{7}$. El viernes 24 de agosto de 1419 llegan a Laurent, cerca de Macon, Andrés, duque de la Pequeña Egipto, y su grupo de gitanos ${ }^{8}$. Se dice de ellos que son hombres de gran estatura y terrible aspecto, con largos cabellos. Tanto los hombres como las mujeres practican las artes mágicas, lo que en estas tempranas fechas ya les acarreó problemas con la justicia real. El 1 de octubre de 1419 aparecen en Sisteron, Provenza, donde se les denomina "sarracenos" ${ }^{9}$ es decir no-cristianos. En 1420, el

- BatallLaRD, Paul, "Beginning of the inmigration of the Gypsies into estern Europa in the fifteen century", Journal of the Gypsy Lore Society, Vol. I april 1889 n. ${ }^{\circ} 4$, págs. $185 / 212$ y Vol. II, 1390, págs. 27/345.

7 Cit. por BATAILLARD, art. cit. pág. 324, „Porro currente ahuc home anno (1418) pervenerunt, kalendis novembribus, ad hanc primum civitatem ignoti et subnigri errones, numero quinquaginta, permagnam etiam jum de formium muliercularum tum foedorum puerulorum catervam saecum ductitanses. Quibus duo duces et, uti ferebant, aliquot comites praerant; profitebanturque se minori Aegipto exulare, et vaticinandi peritos esse. Verum, re penitus introspecta, meri trufures furciferique sunt deprehensi. Hodie nostris "Zegineri», Italis "Cingani» et Gallis «Bohemi» dicuntur...".

8 Citado por BATAILLARD, art. cit. pág. 325., Saint Laurent-lez-Macon está en distinto distrito que Macon, pero únicamente el Saone los separa y un puente une los dos lugares. Bataillard supone que estos gitanos eran los que habían visitado Suiza, y probablemente también habian viajado por el Franco Condado. «Estoient gens de terrible stature, tant en perseones, en cheveix, comme autrementr.

9 Citado por BatAILlARD. art., citado, pág. 328. "Hist. de Sisteron. loco cit" "Quod, amore Dei, istis Sarracenis qui venerunt ad hanc civitatem Sistarici, et qui vagant per universum orbem, penitentia, ut de attento quod eleemosynam pecierunt a dicta universitate pro dando eis discessum ab hac civitate, racione mali quod faciunt, dentur eis de bonis universitatis ea que sequuntur, pro uno prandio, sic eta aliae universitates Provinciae in quibus fuerint fecerunt. Et primo, duas cupas vini puri, que valent quinque grossos, ad racionem. IIII alborum pro qualibet 


\section{duque Andrés alcanza hasta los Países Bajos. En 1422 visitan Tourain por segunda vez ${ }^{10}$ originando protestas entre los vecinos que consideraban en peligro sus bolsas. El mismo año de 1422 llega a Bolonia el duque Andrés, donde se quedaron 15 días recibiendo la visita de muchas per- sonas que fueron a oír las predicciones que hacía la mujer del "duque»".}

cupa, monete albe, computando cartum pro tribus denariis. Item centum panes, quemlibet unius pataci monete albe. Item IIIlor eminas civate, que valent, secyndum quod nunc veduntur, unum flor, albe monete, ad racionem trium denariorum pro carto. Precipentes clavario (tresorier) dicte universitatis quatenus ita faciat crastino die in prandio, et ista omnia facial apportari ultra ad pratum Balme ubi sunt ipsi lochati more gencium armorum, et presententur quidam (sic) duci ipsorum qui est proceles (sic) inter esc ex parte universitatis, amore Dei (1419-Ler. Octobre Regist. des deliberations).

10 He aquí el texto citado por Bataillard en su artículo:

"Y al año siguiente, que era el mil cuatrocientos veintidos, en el mes de mayo, varias personas de una extraña nación que dijeron venian de Egipto, llegaron por primera vez a la ciudad de Tournai y su comarca. Y dijeron que sólo se podían alojar durante Ill dias en la ciudad, porque estaban obligados a viajar como peregrinos alrededor del mundo durante VII años antes de que pudieran regresar a su pais. $Y$ estos Egipcios tenian un rey y señores a los que obedecian y llevaban privilegios para que nadie castigarles.

Y la mayor parte de ellos vivían de robar, especialmente las mujeres que iban muy mal vestidas, y entraban en las casas, algunas pidiendo limosna y otras preguntando por cualquier clase de mercancía. Y resultaba difícil estar en guardia y no perder alguna cosa. Hubo algunos que, para engañar mejor a los tontos, aseguraron que predecian el futuro, por ejemplo si se iba a tener un niño, o si una mujer se iba a casar pronto, o si se tendrían buena o mala suerte, y otras cosas similares. Y mientras estaban engañando de esta manera a mucha gente, los niños cortaban las bolsas de los que ponian demasiada atención a sus engaños, o ellos mismos, con la mano con la que simulaban sujetar al niño (lo que no hacian porque el niño estaba sujeto por una tela puesta alrededor y cubierta con una manta y esta mano quedaba libre) robaban con habilidad sin que se notara.

Y los hombres iban bastante bien vestidos, y la mayor parte de ellos se ocupaban en vender y comprar caballos, y eran tan expertos jinetes que un caballo resultaba mucho mejor debajo de ellos que debajo de los demás. $Y$ asi, "heudelant" - se desconoce el significado exacto de este término que sólo aparece en este texto, señala también Bataillard-y engañando, muy a menudo conseguian mejores caballos que los suyos, y dinero en sus bolsas. $Y$ algunos de estos hombres, cuando compraban alguna mercancia, daban un florin de pago, y al recibir el cambio, eran tan habiles con sus manos, confundiendo y engañando a la gente, 0 pidiendo otro dinero que el que se les daba, que nadie escapaba sin pérdida. $Y$ a menudo, cuando habian robado lo que podian, no se quedaban con la mercancia asegurando que no conocian el dinero que se les daba como cambio.

$Y$ estas gentes se alojaron en la plaza del mercado de Tournai, donde muhos fueron a verles de día y de noche. Y durmieron alli en parejas, cerca los unos de los otros, y no les daba verguenza de hacer sus necesidades delante de todo el mundo.

Y la gente comentaba la afirmación que habían hecho de proceder de Egipto, pero en realidad, según se supo después, eran de una ciudad de Alemania llamada en latín "Epipolensis" (sic) y en lengua vulgar "Mahode", situada entre la ciudad de "Wilsenacque", y "Romme" (sic) a VI dias de viaje desde la mencionada "Wilsenacque", y huyeron de alli a causa de la servidumbre y los tributos "Recueil des cronices des Flancre" publicadas bajo la dirección de la Real Comisión de Historia, por SMET, J.J. Bruselas, 1856, vol. 1II, pág. 372. "Colectión des Chroniques belges".

1 Clebert, J. P., reproduce en su libro Los gitanos. Barcelona, Aymá 1965. Epílogo de J. Caro Baroja. "Los gitanos en la Literatura española", el siguiente fragmento de la crónica que describe la llegada de los gitanos a Bolonia:

"Mucha gente fué muy respetuosamente al encuentro de la mujer del duque (Miguel) para hacerse decir la buenaventura por ella; $y$, si efectivamente pasaron muchas cosas; algunos se enteraron de su futura suerte, pero, en todo caso, ninguno regresó sin que le hubieran robado su bolsa, tal o cual prenda de su vestuario. Las mujeres de este pueblo recorrian la ciudad de seis a ocho de la tarde, exhibian sus talentos en las casas 
A pesar de esta expectación, también se les acusó de que sus mujeres entraban en las tiendas, y con el pretexto de ver las mercancias, robaban muchas cosas.

Después de su visita a Bolonia, y un poco más tarde a Forli, los gitanos anunciaron su intención de dirigirse a Roma. Bataillard considera que ya había transcurrido demasiado tiempo desde que consiguieron la carta de presentación del Emperador de Alemania y, por tanto, se proponían renovar su caducado crédito con alguna credencial del propio Papa, lo que consiguieron, al parecer; a través de algún intermediario, ya que no tenemos noticias de su entrada en Roma.

También en 1422 llegan a Bale. Ratisbona lo visitan en dos ocasiones, en 1424 y 1426, y, finalmente, en 1427 se presentan en París, visita de la que nos ha quedado un estupendo documento que merece la pena analizar detenidamente. De acuerdo con el anónimo cronista del Diario de un burgués de París, la imagen que producen los gitanos reune las mismas características que ya se han perfilado en las ciudades anteriores, pero el autor de esta crónica las ha resumido con tal maestría que a través de su testimonio el lector podrá tener el mejor resumen posible de la impresión que produjeron los gitanos a los europeos del primer cuarto del siglo Xv:

“... Ilegaron a París doce penitentes, según ellos decían, a saber un duque, un conde, y diez hombres, todos a caballo, que se decian buenos cristianos, procedentes del Bajo Egipto. Aseguraban, asimismo, que antes también habian sido cristianos, que estos les habían sometido no mucho tiempo atrás, tanto a ellos como a todo su país, y que los habían hecho convertirse o morir a los que rehusaban a cambiar de credo. Los recién bautizados siguieron siendo señores de la región como antaño... Algún tiempo después de haber ellos abrazado la fe cristiana, los sarracenos los asaltaron, se rindieron a estos enemigos, y volvieron a ser sarracenos renegando de nuestro Señor.

de los burgueses y se apoderaban de todo cuanto quedaba al alcance de sus manos. Otras entraban en las tiendas simulando querer comprar, pero en realidad, era exclusivamente para robar. En toda Bolonia, los latrocinios se produjeron en gran escala. El resultado fué que se publicó un bando diciendo que se multaría con cincuenta litas y la excomunión a todo aquel que tuviera tratos con aquellos extranjeros...

Estos vagabundos son los ladrones más habiles del mundo. Cuando no les quedó nada para robar, se fueron hacia Roma. Hay que notar que no existen peores engendros que estos salvajes. Delgados y negros comían como cerdos. Las mujeres circulaban en camisa, apenas cubiertas llevaban aros en las orejas y muchos oiros adornos. Una de ellas dió a luz a un niños en una plaza pública, pero a los tres dias circulaba como las demas...

Muratori, Crónica di Bologna, 1749, Citado por J.P. Clebert, Ludovico Antonio Muratori Rarum italicarum scriptous (cittá di Castello 1916) tomo 18 (Corpus chronicoum Bonenensium) Parte I, págs. 568-570. 
Ocurrió más tarde que los cristianos, como el emperador de Alemania, el rey de Polonia, y otros señores, enterados de que habían procedido con tanta falsía al abandonar sin mayor trabajo nuestra fe para retornar a su condición de sarracenos e idólatras, les atacaron y vencieron con facilidad, pues los derrotados pensaron que los dejarían otra vez en su país como antes, con la condición de hacerse cristianos. El emperador y los demás señores, luego de larga deliberación en consejo, decidieron que en lo sucesivo los vencidos no poseerían tierras en su propio país, hasta que el Papa no consintiera en ello, para lo cual era conveniente que fueran a ver al Santo Padre a Roma. Hacia allá marcharon todos, grandes y pequeños, con gran sufrimiento de los niños. Al llegar hicieron confesión general de los pecados. El Papa les ordenó como penitencia, que durante siete años consecutivos anduvieran por el mundo sin acostarse en lecho. Como ayuda de gastos dispuso que todo obispo o abad portador de báculo les diera por una sola vez diez libras tornesas; les entregó cartas para los prelados de la iglesia en las que hacia mención de lo por él dispuesto, y les dió su bendición.

Se marcharon, pues, y erraron por el mundo durante cinco años antes de llegar a París los doce de que he hablado, el 17 de agosto de 1427. El día de San Juan el Degollado llegó el resto de esta gente, a la que no se dejó entrar en la ciudad. Sin embargo, por decisión de la justicia, se les alojó en la Chapelle Saint Denis. No eran en total, entre hombres, mujeres y niños, más de cien o ciento veinte personas. Cuando salieron de su tierra habían sido mil o mil doscientos, los que faltaban habían muerto en el camino.

Durante su estancia en la Chapelle hubo tal afluencia de gentes de París, de san Dionisio y de los alrededores de París, deseosas de ver como jamás las hubo ni para la bendición del Bendito. Bien es verdad que tanto muchachas como varones eran más astutos que nadie. Casi todos tenían ambas orejas perforadas y llevaban en cada una de ellas uno o dos aros de plata, decían que en su país era signo de nobleza.

Los hombres eran muy negros, de cabellos crespos. Las mujeres las más feas y oscuras que puedan verse. Todas tenían el rostro surcado de arrugas, cabellos negros como la cola de un caballo y vestían una vieja manta muy ordinaria, prendida al hombro como un lazo de paño o de cuerda, y bajo esa prenda, como todo adorno, un pobre corpiño con una camisa. Eran, en suma, las criaturas más miserables que jamás se haya visto en Francia. A pesar de su pobreza, había entre ellos brujas que adivinaban examinando las líneas de la palma de la mano, lo que a uno le había ocurrido o habia de pasarle. Con sus afirmaciones trajeron dificultades a varios matrimonios, pues le decían al marido, "Tu mujer te ha engañado" o a la mujer: "tu marido te es infiel".

Lo peor era que mientras hablaban a los curiosos, ya por arte de magia, o por otro procedimiento, ya sea por obra del enemigo que está en el infierno, o por hábiles manejos, les vaciaba de dinero la bolsa para engrosar la propia, según se decía. A la verdad yo estuve en el lugar tres o cuatro veces para hablar con ellos y nunca advertí que hubiera perdido una moneda, asi como tampoco los ví a los que adivinaban por medio de las manos de la gente. Eso se afirmaba por todas partes, sin embargo, 
tanto que la noticia llegó hasta el obispo de París, quien fue en persona al lugar llevando consigo a un eclesiástico hermano menor de la Orden, a quien llamaban el pequeño Jardoin. Este, por orden del obispo, les echó un buen sermón, excomulgando a quienes, hombres y mujeres, hubieran practicado tal adivinación o creído en ella. Al final, tuvieron que marcharse. Partieron el día de nuestra Señora, en septiembre, rumbo a Pantoise ${ }^{12}$.

Como vemos, todos los documentos que describen la llegada de los gitanos a Europa coinciden en hablar de sus artes mágicas, unidas a su habilidad para apropiarse de lo ajeno. Los gitanos provocaban una mezcla de curiosidad y temor que resultaba muy a propósito para realizar ambas cosas.

Nuestra minoría, por tanto, queda incorporada a partir de estas fechas a los paisajes europeos como un elemento exótico, caracter que mantendrán hasta nuestros días. Los rasgos esenciales del "mito" gitano han quedado acuñados a partir de estos textos: ladrones y adivinos, atractivos, pero marginales.

¿Qué tienen estos gitanos que ver con los grupos que salieron de la India, probablemente hacia el siglo Ix? Resulta difícil pronunciarse. El idioma es probablemente el rasgo más representativo, las únicas señas de identidad que pudieron recoger los estudiosos del siglo XVIII y XIX para identificarles, y pocos rasgos más. Cuando las bandas gitanas alcanzan Europa son, en cualquier caso, un pueblo nómada, pobre y desharrapado que tiene que recurrir al robo en muchas ocasiones para sobrevivir. Aunque no tengamos ninguna noticia concreta acerca de las razones que obligaron a los gitanos a abandonar la India es probable que, al igual que en el caso de Persia y Armenia, fueran las turbulencias internas del país las que les movieran a dejar su lugar de origen. Tanto si los gitanos salen de la India a causa de una crisis de subsistencias, como si lo hacen motivados por alguna causa de tipo político, es evidente que quienes actuaron así no contaban con una situación cómoda en su propio lugar de origen. Según hemos visto al principio, es también bastante probable que los gitanos pertenezcan al mismo grupo de hombres que los llamamos "dom", es decir a una casta inferior cuya especialización laboral se orienta hacia los trabajos de herrería, el nomadeo, y la actuación como músicos y bailarines. Un bagaje, por tanto, muy útil para sobrevivir a lo largo del camino, pero ciertamente escaso cuando se trate de llevar a cabo asentamientos estables.

12 "Journal d'un bourgeois de Paris sous François ler." Paris, Union Général d'Editions, 1963. 
Los gitanos, por otra parte, irrumpen en Europa en plena baja Edad Media, cuando la hora del capitalismo ha sonado ya desde hace tiempo. Europa mira ya con extrañeza a estos nómadas de lengua y aspecto chocantes en un período en el que la estabilidad de la población es para los habitantes europeos la nota predominante. El choque, por tanto, entre estos dos grupos de población tan distintos, el nómada recién llegado que parece más próximo a los lejanos tiempos de las invasiones bárbaras, y los tranquilos burgueses y campesinos de un período de activo comercio y expansión de los estados nacionales no podía ser pacífico. Los ecos de este enfrentamiento están en la legislación de los distintos países de Europa y la propia documentación que acabamos de resumir.

\section{EVOLUCIÓN DE LA MINORIÁ GITANA DURANTE LOS SIGLOS XV, XVI $Y$ XVII: LA POLITICA ESTATAL}

\section{Los gitanos en España. Periodización de la historia gitana}

La llegada a España de los gitanos tiene características muy similares a las que hemos visto para el resto de Europa, Amada López de Meneses recogió sobre esta etapa una serie de documentos sumamente interesantes que constituyen una cita obligada, al igual que los artículos de Sampson o Bataillard para la aparición del grupo en los países al norte de los Pirineos. Según señala López de Meneses, es posible que los primeros gitanos que penetraron en la Corona de Aragón fueran los mismos que habían visitado Bolonia y París ${ }^{13}$. Alfonso $V$ les concede permiso el 12 de enero de 1425 para viajar por sus dominios durante un trimestre a don Juan, autodenominado "conde" de Egipto Menor. Todos los "condes" y "duques" gitanos que llegan hasta la corona de Aragón y hacen una incursión a Jaén durante este periodo de 1427-1462 añaden a sus títulos el apelativo de la “Pequeña Egipto», es decir, todos debían proceder del área de Chipre y Siria que se conocía con esta denominación durante la Edad Media ${ }^{14}$. El 8 de mayo del mismo año llega también, el conde Tomás, de Egipto Menor, obteniendo los mismos privilegios. Al pasar la familia de este conde por la villa de Alagón les robaron dos perros blancos, que las justicias les devolvieron ${ }^{15}$. El 26 de noviembre de 1434 es

\footnotetext{
13 López dE MENESES, Amada, "La inmigración gitana en España en el siglo xv", Martínez Ferrando. Miscelánea de Estudios, 1968, págs. 239 a 263.

${ }_{14}$ Según Cooper, Fay, ("Gran Enciclopedia del Mundo». 1962.- Bilbao) el área de Siria, Chipre y territorios próximos eran conocidos durante la Edad Media como medio Pequeño Egipto". Citado por Amada López de Meneses. "Miscelánea de Estudios".

15 Archivo de la Corona de Aragón. Cancilleria Real. leg. 2483 fol. 136 r. Citado por López de Meneses, A., "Miscelánea de Estudios».
} 
el conde don Tomás, quien pide copia de la carta de paso de 1425, y el 25 de abril se le concede un tercer salvoconducto a este don Tomás, conde de Egipto Menor. El 23 de mayo de 1435 tenemos noticias de que volvieron a cruzar los Pirineos, puesto que el recaudador del peaje de Jaca y del puesto de Canfranc les reclamó el impuesto, especialmente porque llevaban "cabayos, ropas de seda, oro, argent, e otras averias" ${ }^{16}$. Don Tomás exhibió el documento en que el rey de Aragón le autorizaba para que «con sus gentes et familia fuesse por el mundo en pelegrinación por la fe christiana" ${ }^{17}$ y que pudiera pasar sin pagar el peaje. Al igual que en los demás países europeos, los gitanos se presentan en España como peregrinos, en este caso hacia Santiago de Compostela.

El viernes 9 de junio de 1447 llega un nuevo grupo de gitanos con sus líderes a la cabeza, un conde y un duque. He aquí la descripción que nos ha quedado de ellos: «Lo dia present entraren en la present ciutat un Duch e un Comte ab gran multitut d'Egiptitans o boemians, gent trista e de mala farga e methiense molt en devinar algunes ventures de las gentes" ${ }^{18}$. Hasta 1447, trece años después, no volvemos a tener noticias de nuevos grupos. Según López de Meneses los núcleos primitivos se dividen ahora en nuevas bandas para facilitar sus movimientos. El 4 de marzo de 1460 se extiende de nuevo un salvaconducto a un líder gitano, esta vez "Hacques in Minori Egipto comiti», también camino de Santiago de Compostela y otros sitios devotos. Iba en compañía de unas cien personas. Todavía hay dos condes gitanos más a quien se concede salvoconductos, don Tomás y don Martín, el 23 de marzo y el 21 de abril de 1460 respectivamente. Don Martín lo recibe en Castellón de la Plana, y estos condes gitanos son los que hacen su aparición en Jaén el 22 de noviembre de 1462 , viaje del que volvemos a tener un documento lo suficientemente amplio e interesante como para remitir a él al lector. Los gitanos de los que habla la crónica del condestable y canciller mayor del rey de Castilla Enrique IV tienen rasgos amables y la convivencia entre ellos y los castellanos resulta perfecta, a pesar de algunas características de estos hombres y mujeres que recuerdan a las descritas por el autor por el autor de la Crónica de un burgués de París. Oigamos al autor castellano:

"A veynte e dos dias del mes de noviembre deste año llegaron a la dicha cibdad de Jahén dos condesde la pequeña Egipto, que se llamaban

16 Citado por López de Meneses, A., "Miscelánea de estudios"

"Citado por LóPEz DE MENESES, A., "Miscelánea de estudios"

18 Citado por M. López-Barahona 1892-1922, tomo I, pág. 17. 
el uno don Tomás e el otro don Martín, con fasta cient personas de onbres e mugeres e niños, sus naturales e vasallos. Los quales avian seydo conquistados e destruydos por el Grant Turco; e porque después de ser conquistados paresçe ser que negaron nuestra santa fé, avia buenos dias que, por mandado de nuestro muy Santo Padre, andavan por todos los reynos e provinçiasde la cristiandad faciendo penitençia,

E como llegaron a la çibdad de Jahén, el señor Condestable los recibió muy onorablemente, i los mandó aposentar i facer grandes corras. E quince o veynte dias que estovieron con él, continuamente les mando dar todas las cosas que ovieron menester, a ellos $i$ a toda su gente, de pan, i vino, i carne, i aves, i pescados, i frutas, i paja, i cevada, abondatemente.

$E$ muchos dias los dichos condes comieron con él i con la señora condesa su muger; $i$ al tienpo que se quisieron partir, mandóles dar de su cámara muchas sedas i paños, de que vistiesen, i buena copia de enrriques para su camino. E salió con ellos quanto media legua fuera de la dicha çibdad de Jahén, por manera que los dichos condes partieron dél muy contentos y pagados, loándose i maravillados mucho de su grant liberalidad i franqueza».

Cuando ya han transcurrido solamente unos cuantos años resultará absolutamente impensable encontrar un texto similar. No obstante, en 1470 el conde Jacobo, y quince días después el duque Pablo, visitan también a Miguel Lucas de Iranzo, según de cuenta con puntualidad su crónica, a la que recurriremos de nuevo:

"Dende a quince dias que vino a la dicha çibdad de Andujar, aportó por ella un cavallero que se llamava el conde Jacobo de la Pequeña Egipto, con su muger la condesa, que llamaban doña Loysa, i con fasta çinquente personas, onbres, i mugeres e niños, que traya en su compañia. Los quales andavan asi por el mundo, segund diçian i mos travan por çiertas letras, faciendo penitençia por mandado de nuestr muy Santo Padre porque sus anteçesores dis que avian fallesçido en la creençia de nuestra santa fe por miedo i temor del Grand Turco, de quien avian seydo conquistados i sojuzgados.

Si porque entre otras letras trava una carta del dicho señor rey, por la qual su alteza enbiava mandar a todos lo grandes i subditos i naturales destos sus reynos que oviesen recomendado al dicho conde Jacobo, i la ficiesen toda onor i buen acogimiento, como por se gente estrangera y andar como pelegrinos en aquella manera, el dicho señor Condestable los mando resçibir y aposentar en la dicha çibdad. Y le fizo mucha onrra, faciendo comer al dicho conde i a la condesa su muger todos los dias que en la dicha çibdad estovieron con él y con la señora condesa su muger, y mandado dar a todos los otros todas las cosas que avian menester.

E des que ovieron alli estado çinco o seys dias, mandoles ayudar de su camara lo mejor que pudo, con alguna copia de enrriques para su viaje y mandoles dar su carta para que todas las çibdades i villas i logares que en estos reynos estavan a su cargo i governación les ficiesen todo 
onor e buen acogimiento. De todo lo qual el dicho conde i todos los que con él venían se partieron dél muy contentos y alegres loándose mucho del dicho señor Condestable, de las grandes ayudas y merçedes que dél avian reçebido.

$Y$ dende a quince dias, o poco mas, llegó a la çibdad de Andujar otro cavallero que se llamava el duque Paulo de la Pequeña Egipto, con çierta conpañia de onbres y mugeres. El qual así mesmo traya cartas del rey nuestro señor i letras del rey de Francia, y de otros duques y grandes señores, de cómo andava por el mundo en pelegrinaçión, faciendo penitençia.

Al qual el dicho señor Condestable hizo mucha onrra, segund a la dignidad de su título duçal requería. $E$ al tienpo que se ovo de partir, le mandó dar su letra $i$ ayudalle para su viaje y camino; usando de aquella liberalidad que nunca a ninguno negó» ${ }^{19}$.

Todavía nos quedan por conocer nuevos líderes gitanos que hacen su aparición en fechas un tanto posteriores: el conde Juan de Egipto, que obtenía un salvoconducto en Barcelona en febrero de 1474, y un líder gitano que visitó Madrid, sin que sepamos su nombre.

Además de estos núcleos de gitanos que llegan hasta la península en la primera mitad del sigloxv, todavía tenemos noticias de algunos, procedentes al parecer de Grecia, que entran también a España huyendo de la presión de los turcos. Esta segunda oleada gitana es la de los "grecianos" según se autodenominaban al parecer, de los que también reunió noticias Amada López de Meneses ${ }^{20}$ quien considera que llegaron desde el Mediterráneo a partir de 1448. Respecto a esta segunda etapa de la penetración gitana tenemos noticias de los salvaconductos que se concedieron a "Johannes de Grecia, militis", y conjuntamente a "Johannes et Georgius de Grecia», ambos salvoconductos de 1488. En 1491 el infante Enrique daba su protección a Francesc de Negropont, caballero, y a su comitiva, y tenemos noticias de que un tal Andreu Carranza Catala, «Grecus dux et capitaneus millorum Grecorum tan marium quam faminarum" se embarcaba en Córcega con el propósito de venir a España para hacer una peregrinación a Santiago de Compostela. El 2 de agosto de 1496 era "Franciscus de Arilo, miles de natinione Grecorum», quien llegaba "cum sua gente et comitiva et cum suis servitoribus equestribus et pedestribus pro sua et eorum penitencia complenda per regna Aragonum et Castelle

19 "Hechos del Condestable D. Miguel Lucas de Iranzo" (Crónica del siglo xv). Edición y estudio por Juan dE MATA CarRIAZo. Madrid. $\varnothing$ Espasa-Calpe.- 1940 (pag. 416).

${ }_{20}$ LÓPEZ DE MENESES, Amada, "Noves dades sobre la inmigració gitana a Espanya al segle Xv". ("Estudis d'Historia Medieval»). Barcelona. Institut d'Estudis Catalanas. 1971. pags. 145 a 159. 
peregrinare conatus est, ${ }^{21}$. Como vemos, estos nuevos líderes gitanos ya no se presentaron con los altisonantes títulos de "condes" y "duques", sino que se consideraban como capitanes y conductores cuyo origen ya no es el de Egipto Menor. Algunos han tomado ya nombres relacionados con la cultura del reino de Aragón, lo que parece indicar que habían tenido algún contacto previo.

En la Corona de Castilla también se otorgó salvoconducto a estos nuevos visitantes, y en Medina del Campo se concede el 27 de julio de 1497 dos cartas de recomendación, una para Francesc d'Arguiro, «cavalier de Grecia", ya que, "Nuestro sancto Padre le mandó qu'él, çierta gente de su nación que trae en su companya de pie e de cavallo, omes e mugeres en penytençia, visitasen çiertas yglesias e monesterios». La otra carta de recomendación es para Juan de Bonafé, "caballero griego". Según vemos, la excusa que utilizan los "grecianos" es la misma que sus compañeros de Egipto Menor: visitar Santiago de Compostela y otros lugares sagrados.

Los grupos gitanos que llegan a la península a lo largo del siglo xV son, por tanto, pequeñas bandas de hombres y mujeres que oscilan entre las 50 y 100 personas, según se menciona en los documentos que acabo de pormenorizar. En ambos casos se reunen en torno a un líder, y parecen demostrar una gran movilidad: Si tenemos en cuenta los grupos señalados por López de Meneses en la primera oleada ${ }^{22}$, y los escasos nombres de la visita de los grecianos, los gitanos que eligieron España como nuevo

21 Citado por lópez de Meneses, A. art. cit. Torre del Cerro, A., “Documentos para las relaciones diplomáticas de los Reyes Católicos». Madrid 1949-1966, V, 305-306.

${ }^{22}$ La lista de acondes y gitanos la resume así la propia LóPEZ DE MENESES, Amada, en Novedades..

Don Juan de Egipto Menor. 14 de agosto de 1425 (Zaragoza).

Don Tomas, Conde de Egipto menor. 8 de mayo de 1425 (Zaragoza) 9 de junio de 1447 (Barcelona) 23 de mayo de 1460 (Barcelona).

Don Andrés, duque de Egipto Menor. 9 junio 1447

Don Pedro, conde de Egipto Menor. 9 junio 1447 (Barcelona).

Don Martin, conde de Egipto Menor. 9 de junio 1447 (Barcelona) 4 de abril de 1460 (Daroca) 21 de abril de 1460 (Castellón de la Plana) 24 de septiembre de 1471 (Lleida) 29 de octubre de 1472 (Valencia) 29 de mayo de 1484 (Castellón de Ampurias) marzo de 1491 (Sevilla).

Don Jacobo, conde de Egipto Menor. 4 marzo de 1460 (Daroca), 23 de marzo de 1460 (Tarazona), 23 de mayo de 1460 (Igualada), 31 de enero de 1471 (Zaragoza), 23 de septiembre de 1480 (Medina del Campo) 24 de enero de 1486 (Barcelona) marzo de 1491 (Sevilla).

Don Pablo de Egipto Menor. 28 de junio de 1470 (Zaragoza).

Don Miguel, conde de Egipto Menor, 30 de mayo de 1472 (Zaragoza)

Don Juan, conde de Egipto Menor, 28 de febrero de 1474 (Zaragoza) 4 de sepitiembre de 1475 (Burgos), 16 de septiembre de 1476 (Logroño).

Don Luis, conde de Egipto Menor, 29 de mayo de 1484 (Castellón de Ampurias) 24 de enero de 1486 (Barcelona) marzo de 1491 (Sevilla). 
hogar a partir de este período no podían exceder las 2.000 ó 3.000 almas a lo sumo. Un número muy reducido de personas, pero con escasas posibilidades de ganarse la vida y una gran facilidad para trasladarse de un lugar a otro según puede observarse en estos mismos documentos. Don Martín, don Tomás, don Jacobo y don Pablo penetran hasta Jaén y Andújar, en 1462 y 1470. Uno de estos condes llega hasta Madrid, y por Castilla circularon también don Felipe, don Luis y don Jacobo en $1491^{23}$. Estos mismos Felipe y Luis son, probablemente, los que habían estado en Castellón en 1484.

La situación de estos nómadas debía ser, seguramente, muy difícil y explica la aparición de los primeros conflictos. A pesar del tono "idílico" de la crónica de don Miguel Lucas de Iranzo y de otros documentos a los que me referiré más tarde, incluso en estos primeros momentos se pueden observar ya los síntomas de un conflicto que va a causar serias preocupaciones a la Corona durante los siglos siguientes. El 30 de septiembre de 1482 Pere Soldevila comparecía ante la corte de justicia de Lérida para denunciar las amenazas de muerte de que había sido objeto por parte de unos «boemians", que, "venuts a la present ciutat moguts per lo sperit maligne, no tement Deu ni la corecció temporal, havient robat a dit Soldevila huit lliures en diners que portova com no portas mem ${ }^{24}$. También había habido serios problemas con un "greciano", un tal Joan de Costa, a quien el 8 de octubre de 1492 el infante Enrique de Aragón dio permiso para que sus gentes ejercieran las artes mecánicas y vendieran sus productos al precio que pudieran concertar con los compradores. Costa abusó de las mercedes de don Enrique, y empezó a exigir un tributo de un ducado a las caravanas que encontraba por los caminos ${ }^{25}$.

Según vemos, a pesar del tono amable de los salvoconductos y otros documentos de los que hablaremos a continuación, se estaba gestando ya un serio conflicto del que todavía tenemos otros ecos. El 25 de enero de 1489 se extiende en Valladolid un salvoconducto para unos mercaderes griegos que han sido maltratados en Sicilia al ser confundidos con gitanos ${ }^{26}$, lo que parece demostrar los primeros síntomas de rechazo hacia

\footnotetext{
23 Archivo General de Simancas. Registro del Sello. Seguro a favor de don Felipe, 1491. fol 62; seguro a favor de Don Luis, marzo 1491, fol. 63; Seguro a favor de don Jacobo, marzo 1491 fol. 61 .

24 Citado por López de Meneses, Amada, Archivo de la Paheria de Lérida, Reg, 823 ff. 71. 74.

5 AGS. Registro del Sello. Enero 1498. fol. 317.

26 AGS. Registro del Sello. Enero 1498. fol 98
} 
ellos. La primera Pragmática dictada específicamente contra ellos por los Reyes Católicos en Medina Sidonia en 1499 es la consagración oficial de unas hostilidades que se extienden a lo largo de toda la Edad Moderna.

A pesar de esto, las relaciones entre los gitanos y los no-gitanos siguen teniendo durante esta primera etapa de la minoría en la Península un aspecto un tanto idílico de acuerdo con algunos documentos, que resulta prácticamente imposible encontrar en los siglos posteriores. El tono «idilico" de las relaciones gitanos y no-gitanos al que he aludido se puede observar con claridad en las noticias de su llegada a Jaén y Andújar, según la describe la crónica de don Miguel Lucas de Iranzo, pero todavía hay otros hechos que contribuyen a distinguir estos primeros años del resto de la historia gitana en España. Desde las primeras fechas de su asentamiento en el país, empezaron los gitanos a participar con bailes en las fiestas del Corpus. Hacia 1478 se les menciona en las de Guadalajara. Una de las gitanas que actuaron en esta ocasión, llamada María Cabrera, atrajó la atención del heredero del ducado, Don Diego Hurtado de Mendoza y Luna. La gitana quiso participar en una competición hípica, para lo que su admirador le consiguió el mejor ejemplar de sus cuadras. La muchacha quedó, "bien para lo que su femenil sesso la obligava" ${ }^{27}$, con lo que terminó de conquistar el corazón del noble caballero, y así, quedó instalada en Guadalajara "para que sin peregrinar viviese", mientras sus compañeros siguieron durante años viniendo a Guadalajara, donde «luego visitasen la casa de los duques como parientes della y se la mostravan, con lo qual yvan muy contentos de tal parentesco". De estas relaciones nació don Martín de Mendoza "El Gitano", hacia 1481, quien fue «hombre de buena estatura y moreno, conforme a su madre" ${ }^{28}$.

Como solía ocurrir con los hijos ilegítimos fue dedicado a la iglesia donde la familia le protegió y consiguió que hiciera una carrera relativamente brillante. Inocencio III le concedía en 1486 un beneficiado en Buendía y en Vélez, y una pensión en Cuenca ${ }^{29}$. En 1499 el cardenal Cisneros le daba licencia para recibir la tonsura, y Julio ll le dispensó de su condición de hijo natural para que pudiera recibir beneficios, nombrándole arcediano de Guadalajara y abad de Santillana ${ }^{30}$. El 30 de junio de 1514

${ }^{27}$ López de Meneses, A., "Un arcediano gitano. Don Martín de Mendoza» (Pomezia, septo. oct. 1968).

28 Citado por López de Meneses, A., art. cit. sup. Madrid, Real Academia de la Historia, Colección Salazar, c. II, manuscrito.

29 Madrid. Archivo Histórico Nacional. Osuna, 969, 2; Osuna 1969, 3 Citado por LóPEZ DE Meneses, A., art. cit.

3o AHN. Osuna, 1967, 7 (12 julio 1507), Osuna 1967, 8 (21 agosto 1508) Osuna. 1968, (3 mayo 1511) Citado por LóPEZ DE MENESES, art. cit. 
la reina Juana le concedió una legitimación temporal considerado "que siendo Don Diego Hurtado de Mendoza y de Luna, duque del Infantado, vuestro padre, onbre soltero no obligado a matrimonio ni religión alguna, vos ovo y procreo en Maria Cabrera, vuestra madre, siendo asy mesmo muger soltera no obligada a matrimonio ni religión alguna". El 11 de julio de 1529, Clemente VII lo confirmaba en la dignidad de arcediano de Guadalajara y Talavera ${ }^{31}$ y en 1535 vivía en Roma, sin embargo, donde el Papa Paulo III le dispensaba de residir en España. Este mismo papa le nombraba notario apostólico en octubre de 1536. Falleció en 1555.

Mientras residía todavía en Guadalajara tuvo amores con una hija de Juan de Cervantes, abuelo del autor de La gitanilla ${ }^{32}$. El 29 de septiembre de 1529 nuestro arcediano se comprometía a dotar a su amante con seiscientos mil maravedis, lo que no cumpló y los amores terminaron en pleito, a pesar de los numerosos regalos con que la había obsequiado. Como vemos, el período abunda en anécdotas, noticias amables, e incluso novelescas. Lo más significativo son, sin embargo, los salvoconductos y permisos concedidos a los gitanos durante el siglo $\mathrm{xV}$, que señalan la entrada de la minoría en nuestro país. Con el fin de llevar hasta el lector el contraste de estos documentos con la serie de Pragmáticas que inauguran los Reyes Católicos en 1499, Veamos a continuación el concedido por Alfonso V a Juan de Egipto Menor, antes de seguir con una historia en la que abundan más los hitos desagradables que los acontecimientos venturosos:

Allousussete Als nobles amats e feels nostres vniuerses e sengles gouernadors, justicies, veguers, sotsueguers, sotbtles, et altres qualuol officials e subdits nostres e encara qualseuol guardes de ports e coses vedades en qualsuol parts de nostres regnes e terres al qual o als quals les presents peruendran e seran prosentades o al lochtinents de aquels. Salut e dilecció. Com l'amat e deuot nostre don Johan de Egipte Menor, de nostra licencia anant en diuerses partes, entena passar por algunes parts de nostres regnes e terres, e vullman aquell esser bentractat e acullit, a vosaltres e a cascun de vos dehim e manam expressament e de certa sciencia, sots incorriment de nostra ira e indignació, que lo dit don Johan de Egipto e los que ab ell iran e l'acompyaran, ab totes ses vaualcadures, robes, bens, or, argent, braces, males e altres qualseuol coses que ab si partaren, lexets anar, star e passar per qualseuol ciutats, visess, lochs e altres parts de nostra senyoria, saluament e segura, tota contradició, impediment e contrast remoguts. Prouehin e donat a aquells segur

31 Osuna, 1878, 7 Citado por López de MENESES, art. cit.

32 Lóez de Meneses, A., "Una gitana, prima de Miguel de Cervantes: Martina de Cervantes", (PomezIA, noviembre 1968). 
passatge e conduyt si e quant per le dit don Johan requests ne serets durant to present nostre salyoconuyt, lo qual volem que dur per tres mesos del dia de la data de la present en auant conument comptadora. Dada en Çaragoça sots nostre segell secret a XII dies de janer. En l'any de la natiuitat de Nostre Senyor Mil CCCC XXV Rex Alfonsus. ${ }^{33}$

Según he señalado antes, los Reyes Católicos inician, con la que publican en Medina Sidonia y Granada en 1499, una larguísima serie de medidas contra los gitanos. De acuerdo con lo dispuesto por ellos en esta legislación recién inaugurada, no sólo no se les autoriza y protege para viajar por el reino, sino que se ordena terminantemente su expulsión en un plazo breve. Como vemos, la política de la Corona respecto de nuestra minoría se modifica radicalmente:

"Mandamos a los egipcianos que andan vagando por nuestros Reinos y Señoríos, con sus mujeres e hijos, que del día que esta Ley fuera notificada y pregonada en nuestra Corte y en las vilas, Lugares que son Cabeza de Partido hasta 60 días siguientes, cada uno de ellos vivan por oficios conocidos y mejor supieren aprovecharse estando de estada en los Lugares donde acordasen asentar o tomar vivienda de señores a quien sirva y les den lo que hobieren menester y no anden vias juntos viajando por nuestros Reinos como lo hacen dentro de otros 60 dias primeros salgan de nuestros Reinos y no vuelvan a ellos en manera alguna so pena que si en ellos fueren hallados o tomados, sin oficio, sin señores, juntos pasados los dichos dias, que den a cada uno cien azotes por la primera vez y los destierren perpetuamente de estos Reinos, y por la segunda vez, que los corten las orejas y estén 60 dias en la cadena y los tornaren a desterrar como dicho es ${ }^{34}$.

También se determina que la tercera que se encuentre a uno de estos gitanos «sin oficio y sin señor» quede cautivo de la persona que lo prenda durante toda su vida, encareciendo a los alcaldes y alguaciles se ocupen de hacer cumplir la Ley. Se trata, indudablemente, de disposiciones muy duras sobre las que es preciso señalar, sin embargo, que están dirigidas contra aquellos gitanos que aceptaran asentarse y tomar "oficio conocido" y no de una disposición dirigida contra toda la minoría por razones religiosas - como se hizo contra los judíos, en la misma época, y más tarde contra los moriscos - o por razones sociales. La pragmática resultaba, a pesar de todo, prácticamente imposible de cumplir por parte de un grupo

\footnotetext{
33 Archivo de la Corona de Aragón. Cancilleria Real. Registro 2573. fol. 145. v. Citado por LóPEZ DE MENESES, Amada, (La inmigración gitana...)

${ }^{34}$ “Novisima Recopilación de las Leyes de España, mandada formar por el señor don Carlos IV». Edic. Facsimil, Boletín Oficial del Estado, Libro XII título XVI.
} 
cuya forma de vida era el nomadeo, y a partir de aquí los gitanos entrarán en abierta colisión con las justicias del reino.

Los Reyes Católicos pretendían que los gitanos se sujetaran a las mismas normas que los demás naturales de Castilla y Aragón, etc., pero el resultado de sus disposiciones será la marginación de la minoría y un largo período durante el cual sobre la cabeza de los «egipcianos», tan bien recibidos durante la primera época, gravitará el peligro de la expulsión del país, y otras penas igualmente duras de las que iremos hablando en su lugar. Las pragmáticas no dejarán de ocuparse de ellos durante el Antiguo Régimen constituyendo la columna vertebral de la historia de los gitanos en nuestro país. De acuerdo, por tanto, con el espíritu fundamental de las leyes sobre gitanos, emitidas, a partir de los Reyes Católicos y hasta Carlos III, la vida de la minoría puede dividirse en las siguientes etapas, según mi punto de vista:

1. 1425-1499 el «período idílico»

Según hemos visto, los gitanos son recibidos con amabilidad y comprensión durante esta breve etapa, y los textos tienen un aire «idílico» de buen entendimiento.

\section{1499-1633 periodo de la expulsión}

Sin duda, se trata de una de las etapas más duras de los gitanos, todavía buscando su asentamiento en el país, y en qué ocuparse. Las pragmáticas emitidas durante esta etapa se ratifican en la voluntad de los Reyes Católicos de expulsar a los «gitanos vagantes» - lo que equivalía, prácticamente a expulsarles a todos- y en medidas dirigidas a lograr este objetivo. Los gitanos debían ser durante esta época, nómadas en gran parte, y están buscando todavía, desde mi punto de vista, su identidad en nuestro pais, lo que explica la dureza del enfrentamiento entre ellos y el campesinado, según veremos.

\section{1633-1783 integración legal de la minoría}

Durante el reinado de Filipe IV se deroga el decreto de expulsión. Los gitanos pasan, por tanto, a formar parte del resto del país, por lo menos, desde el punto de vista legal. Se empiezan a observar asentamientos gitanos y la sedimentación del grupo, pero todavía estamos lejos, sin embargo, de un buen entendimiento.

\section{1783-en adelante. Período de integración}

Carlos III deroga todas las leyes que impiden la entrada de los gitanos en cualquier oficio al declarar que "no proceden de raíz infecta». A partir de este momento comienza la lenta integración de la minoría y la aceptación social por parte de los no-gitanos. 
Como ya habrá observado el lector, la historia de los gitanos en nuestro país es una historia difícil, jalonada de momentos amargos en la que aparece, sin embargo, un progreso lento, casi imperceptible para un observador poco atento. En las páginas que siguen trataremos de seguir este proceso con el mayor detenimiento posible.

\section{Los gitanos condenados como galeotes}

Al igual que otros muchos condenados por los tribunales civiles o inquisitoriales, los gitanos fueron a parar en algunas ocasiones a las galeras reales para cumplir penas que oscilaban entre los cuatro, seis, ocho años, o más, al remo.

Los vagabundos y ladrones -entre los que se incluía a los gitanosasí como los blasfemos, perjuros, rufianes, maridos "consentidores", y los que ocultaban a algún fugitivo a la justicia real, estaban destinados a cubrir estos trabajos forzados desde principios del siglo xvl ${ }^{35}$.

La pena de galeras estaba considerada como uno de los castigos más graves a que podía ser condenado cualquier hombre. Se trataba de una prueba tan difícil de superar que en la legislación de los siglos XVI, XVII y XVIII aparece como el grado superior al que podía ser destinado un reo, lo que condujo, probablemente entre otras razones, a que los legisladores castellanos la destinaran en un principio para conmutar las sentencias precisamente de aquellos hombres a quienes se había sentenciado a muerte. Aunque los fueros viejos de Aragón prohibían que se aplicara este tipo de castigo, excepto contando con el asentamiento del interesado ${ }^{36}$, en Castilla se permitió mediante una cédula del 2 de noviembre de $1502^{37}$ la conmutación de la pena de muerte por la de este castigo.

La actitud del rey Fernando contaba ya con el antecedente establecido en Castilla con motivo de la empresa de Colón. Aunque los miembros de las tripulaciónes de los dos primeros viajes estuvieron compuestas por

35 Acerca de la implantación y evolución de la pena de galeras en España deben verse los estudios de SEVILLA y SOLANAS, Félix, "Historia penitenciaria española (la galera) apuntes de archivo", Tipográfico de El adelantado de Sevilia, 1917, desde el punto de vista fundamentalmente jurídico, y el más reciente de PIKE, Ruth, Penal Servitude in Early Modern Spain. Univ. of Wiscosin Press, 1983, 204 págs. R.P. hace mayor énfasis en las cuestiones de carácter social.

${ }^{36} \mathrm{LEA}, \mathrm{H}$. Ch., hace un resumen de la implantación de la pena de galeras en el Santo Oficio en su monumental trabajo A History of the Inquisition of Spain. Reimp. New York, Ams Press, 1966, 4 vols. (vol. III, cap. III, pág. 141 y ss.)

${ }_{37}$ LEA, H. Ch., ob. cit., ibidem. 
hombres libres y profesionales del mar, durante el tercer viaje ya había disminuido el entusiasmo y la curiosidad quie provocaron los primeros descubrimientos, y el almirante se vio obligado a recurrir a cierto número de ex-presidiarios que se prestaron a la aventura a cambio de redimir las penas de carácter grave a que habían sido destinados. Es decir, se trataba de hombres y mujeres que debían sufrir la de muerte o pérdida de algún miembro, pero se exceptuaba a los que habian traficado con moneda falsa. Todo ello se dispuso mediante una real cédula y entre ellos se encontraban dos parejas de gitanos, Macías y Antonio de Egipto con sus respectivas mujeres ${ }^{38}$. La legislación dirigida a reclutar esta mano de obra imprescindible para las necesidades bélicas del país empieza a comprender cada vez a mayor número de delitos, según cabía de esperar, a medida que van en aumento las contingencias que determinan su aparición.

Esta situación se observa con mucha claridad a través de las sentencias dictadas por el tribunal de la Inquisición contra reos que se consideran merecedores de esta pena. La campaña italiana decide al rey Fernando a solicitar un Breve de Alejandro VI, concedidó el 28 de mayo de 1503, para que el Santo Oficio pueda utilizar este castigo contra algunos condenados $y$, al igual que en Castilla, como un servicio que permitía sustituir la prisión perpetua o el destierro a las colonias. Como consecuencia de esta medida, 19 galeotes embarcaron en Barcelona en 1505 con destino a la conquista de Nápoles ${ }^{39}$.

Circunstancias similares conducen a Carlos I en 1529 y a Felipe II en 1558 a utilizar de nuevo los servicios de estos supuestos culpables. La legislación inquisitorial nos permite ver como se van incorporando a este trabajo los blasfemos, bígamos, y aquellos individuos que intentaron suplantar las funciones del Santo Oficio o las de los sacerdotes diciendo misa sin estar ordenados con penas que oscilan entre los tres y cuatro años de servicio ${ }^{40}$.

\footnotetext{
38 La relación de estos acompañantes de Colón en su tercer viaje fue publicada por GIL, en el "Anuario Bibliográfico de Estudios americanos». SEVILLA y SOLANAS se refiere también a este episodio en los siguientes términos: "... Colón -por no encontrar aventureros que le acompañaron en su atrevida empresa,- que consideraban obra de un vesánico-- le acompañaron en sus primeras expediciones de descubrimiento algunos delincuentes, a quienes se les indultó de la penas aque habían sido condenados, pero con la condición de efectuar estos viajes", Sevilla y Solanas, ob. cit, pág. 29. Debo este dato a la amabilidad de D. Leandro Tormo, del C.S.I.C.

39 LEA, H. Ch., Ob. cit., ibidem.

40 LEA, H. Ch., ob. cit., ibidem.
} 
La situación es muy similar en el caso de la legislación civil. De acuerdo con la justicia real, los ladrones fueron condenados según la pragmática de Don Carlos, Doña Juana y el príncipe Felipe a la pena de galeras a partir del año $1552^{41}$. Se ordenaba sustituir el castigo de azotes a que se les condenaba anteriormente por cuatro años de galeras, en la primera condena, siempre que fueran mayores de veinte años. La segunda vez, recibirían cien azotes y servirian perpetuamente en ellas. Cuando el hurto se hubiera llevado a cabo en la Corte, las penas serían mayores, cien azotes y ocho años al remo la primera vez, y doscientos azotes y galera perpetua la segunda, siempre que superaran esta edad. La misma severidad se muestra con los "vagabundos" a partir de estas fechas. Según la Pragmática de Don Carlos y Doña Juana, también del año 1552, los vagabundos quedaban destinados a las galeras, en lugar del anterior castigo de azotes, durante cuatro años después de la primera condena, cuando el reo tuviera más de veinte años. La segunda vez que se le encontrara culpable, se le destinaría al servicio de galeras, en lugar de la anterior pena de azotes, durante cuatro años, siempre que se cumpliera la misma condición de ser mayor de veinte años. En la tercera ocasión, recibiria cien azotes y sería condenado a ocho años de galeras. en la tercera pasaban a permanecer perpetuamente al servicio real.

Como vemos, la actitud de la Corona hacia los vagabundos era la misma que respecto a los gitanos, aunque los miembros de la minoría ya habian sido condenados a seis años al remo desde 1539 , de acuerdo con la pragmática de Carlos I, y doña Juana, ratificada más tarde por Felipe II en $1560^{42}$. Por lo que se refiere a los miembros de la minoría, las pragmáticas evolucionan de acuerdo con las pautas siguientes, en caso de que se nieguen a aceptar la pena de destierro a que quedaron sujetos hasta el 15 de febrero de 1633:

1539-1560 - 6 años de galeras.

$1633-200$ azotes y 6 años de galeras.

- en caso de que se les encuentre con armas de fuego, la pena aumenta a 8 años de galeras.

$1695-6$ años de galeras para aquel gitano que se niegue a ser registrado en el censo ordenado por Carlos II. Es posible, sin embargo, que este censo no se llevara nunca a cabo.

41 Nueva Recopilación de las leyes destos Reinos hecha por mandado de la Magestad Catholica del Rey Don Felipe don Felipe III, 1640. Edic. facsimil, edit. Lex, 1982.

42 Nueva Recopilación, ed. cit. 
- 8 años de galeras para los que usen armas, vayan acuadrillados o sean encontrados con armas.

1717

- 6 años de galeras y 100 azotes.

- 8 años de galeras y 200 azotes para los que usen armas ${ }^{43}$.

A medida que aumentan las necesidades bélicas del país, los tribunales civiles van ampliando también sus competencias respecto a los delitos que pueden conducir a un condenado al terrible castigo de las galeras. La actuación de estos tribunales parece a este respecto mucho más contundente que la del Santo Oficio. El reinado de Carlos I representa, durante el siglo XV, el primer esfuerzo serio de la Corona para reclutar brazos con destino al servicio del mar, actitud que se incremena con la subida al trono de Felipe II y las contingencias de su reinado. A partir de 1566 se condena a este mismo servicio a los rufianes, a los maridos que consientan el adulterio de su esposa, y a algunos reos procedentes de la jurisdicción inquisitorial. Los bígamos, blasfemos, y perjuros, quienes pasan a recibir castigos similares, según hemos visto.

Según parece evidente, la situación de los gitanos empeora, al menos en teoría, de acuerdo siempre con las tendencias generales de los legisladores respecto a otros grupos similares. En las páginas que siguen podremos observar, sin embargo, que la dureza de las medidas que se pretendían adoptar contra ambos grupos tropezaron en la práctica -afortunadamente para todos ellos - con una variada casuística que obliga a matizar la cruda impresión que produce la lectura de las disposiciones legales. Según las leyes dictadas a propósito de la conmutación de las penas corporales por la pena de galeras - que comienzan a emitirse también a partir del siglo XVI - todos los reos condenados a este tipo de castigos, sin hacer mención de etnia o grupo social, tales como cortarle una mano o pie, destierro perpetuo o alguna situación similar, pueden ver conmutado este castigo por el de galeras por tiempo discrecional siempre que no sea inferior al de dos años, y siempre que no resulte en perjuicio de la "parte querellosa». Así lo dispone Carlos I el 31 de enero de 1530, el 16 de mayo de 1534, y el 23 de febrero de 1535. Carlos, D. Juana en la pragmática de noviembre de 1662, y Felipe ll en la de mayo de 1560 se pronuncian en el mismo sentido respecto a los robos y salteamientos

\footnotetext{
43 Estos datos aparecian ya en mi libro Los gitanos españoles en el siglo xVII. El período borbónico. Madrid, Castellote, 1977,550 págs. También puede verse un capítulo acerca de la legíslación antigitana en España. Los textos completos de esta legislación pueden consultarse en mi libro Documentación selecta sobre la situación de los gitanos españoles en el siglo XVIII. Madrid, Editora Nacional, 1977, 268 págs.
} 
cometidos en los caminos en el campo. Felipe II vuelve a ratificarse a este respecto en la pragmática de 3 de mayo de 1566. Para evitar que la «parte querellosa» pueda impedir la puesta en práctica de esta disposición estipula que «aunque haya perdón por parte, siendo el delito y persona de calidad que justamente pueda ser condenado en pena corporal, sea y pueda ser puesta la dicha pena de servicio de galeras por el tiempo que según la calidad de la persona y del caso paresciere que se puede poner» ${ }^{44}$.

Felipe III endurece la disposición en la real cédula de 3 de septiembre de 1611:

"Mandamos que ningún galeote, que estuviere condenado y llevado a las cárceles de Toledo o Soria, a las demás que se llevan, conforme a la orden que por las leyes y cédulas esta dada, sea oído en pretensión ninguna que toque a su libertad, por ningún caso, como es intentar juicio de inmunidad de iglesia o de enfermedad que impida ir a servir, sino que sin embargo destos y cualesquier impedimentos sean luego llevados desde las dichas cárceles adonde el mismo Consejo de la Guerra hubiere ordenado, sin detener ninguno desde una cadena para otras ${ }^{45}$.

Al igual que en el caso de las pragmáticas anteriores a propósito de los reos destinados directamente a las galeras, la situación de estos desgraciados es preciso analizarla a la luz de la variedad de situaciones que aparecen en los documentos y que proceden en ocasiones del propio Consejo, y en otros, a través de la práctica cotidiana de la justicia. Según parece, las excepciones a estas medidas tan estrictas respecto a la conmutación de las penas corporales no fueron excepcionales. Los hombres destinados a este servicio no carecían, sin embargo, totalmente de recursos para apelar a la justicia y tratar, a través de este recurso legal, de conmutar el castigo o atenuarlo.

Con alguna frecuencia, según veremos a continuación, los galeotes consiguieron la libertad mediante indultos o sustituir este destino por otro más benigno, pero, por lo general, las necesidades de la guerra obligaron a los monarcas a intentar con cierta frecuencia levas que les proporcio-

44 Las disposiciones respecto a las penas corporales se encuentran recogidas en la Novísima Recopilación de las Leyes de España mandada formar por el Señor deo Carlos IV. Ed. facsimil del B.O.E. 4 vols. (Libro XII, título XL. ley I D. Carlos I en Madrid, pragm. de 31 de enero de 1530, 10 de mayo de 1534 y 23 de febrero de 1535, ley II D. Carlos y D. Juana en Monzón, Pragm. de 25 de nov. de 1552 y Felipe II en Madrid, pragm. de mayo de 1566. ley III, Felipe II en pragm. de mayo de 1566, ley IV el mismo en dicha pragm.).

${ }_{45}$ Nueva Recopilación, lib. VIII, titl. 24. ley XI. («Novisima Recopilación...» lib. XIII, tit. XL, ley V). 
naran los presidiarios - "chusma" se dice en los documentos de la época - imprescindibles para sus objetivos.

En consecuencia con la legislación que acabamos de revisar, a lo largo de los siglos XVI y XVII aparecen con cierta frecuencia testimonios acerca de los condenados a este tremendo castigo, que muchos consideraban peor que la muerte o cualquier desgracia. En 1571, por ejemplo, Felipe II se dirigía en los siguientes términos a los alcaldes de Sevilla para reclamarles el servicio de estos hombres:

«El Rey. Nuestros alcaldes de la quadra de la ciudad de Sevilla. Ya sabeis como por nuestra carta de veinte e quatro de enero deste presente año mandamos escrivir que porque havíamos mandado que las quatro galeras que estavan en el puerto de Santa María se aprestasen y pusiesen en horden e tenían mucha falta de forzados enbiasedes a ellas lo que ouviese en la cárcel desta audiencia condenados a galeras según mas largo en la dicha carta a que nos referimos se contiene. $E$ aora don Juan de Mendoça nuestro capitán general de las galeras de España nos ha hecho relación que en esa dicha carcel ai muchos condenados a galeras que se podrían enbiar a que otros que tambien están condenados a galera en primera instancia que por haver apelado o llamarse a la Corona no siguen sus pleitos en grado de apelación porque saben que no tiene justicia y huelgan de estar en la carcel con esperança que algun dia la quebrantaran y se yran e algunos desta calidad que ha mucho tiempo que estan en la dicha carcel: Suplicandonos que lo susa dicho es de mucho inconveniente para nuestro servicio fuesemos servido mandar que embiasedes a las dichas galeras todos los qualesquiera condenados a ellas en la dicha carcel y que a los que están en grado de apelación y se ouvieren llamado o llamaren a la Corona les mandasedes que dentro de seis meses acaben sus causas y que no lo haziendo asi lo entregaseden en dichas galeras como mandamos que se hiziese en la ciudad de Malaga, o como la nuestra merced fuese. E porque por la necesidad que ai de que las dichas galeras se armen e pongan en orden lo havemos tenido por bien. $E$ os mandamos proveais que se envien a las dichas quatro galeras todos los que ouviere condeandos para ellas en la dicha carcel como os lo tenemos escripto. $E$ que todos los que en ella condenados a servicio de galera que sus causas estubieren en grado de apelación o que se aian llamado o llamaren a la Corona que dentro de seis meses desde el día que ouvieren en apelación no estubieren seniados en revista 0 dados por libres, los entregueis en las nuestra galeras para donde fueren condenados sin embargo de las tales apelaciones. Fecha en Toledo a -blanco- de março de mil e quinientos y setenta e un años" ${ }^{46}$.

Según vemos, el rey apremiaba a los alcaldes para que los condenados fuesen a cumplir su servicio en las galeras con la mayor brevedad

46 Archivo General de Simancas. Guerra Antigua, leg. 70, n. 373. 
posible, de acuerdo con la gran demanda que el país tenía en aquel momento de brazos que le defendieran en el mar. La situación se repite periódicamente durante el reinado de Felipe II, y entre los años 1572-75 se ordena una medida similar, destinada en esta ocasión a todas las justicias del reino. Es decir, se intentó llevar a cabo una leva general de hombres destinados al remo. En esta ocasión, los alcaldes, corregidores y demás justicias del reino enviaron sus testimonios acerca del número de condenados a galeras que había en sus calabozos, lo que nos permite disponer de noticias concretas acerca del número de gitanos que quedaron comprendidos en la medida, y que cayeron en las redes de la justicia al mismo tiempo que otros infelices similares.

$\mathrm{Si}$ tomamos en cuenta las noticias anteriores aunque los gitanos se encontraron entre los primeros que fueron destinados a cumplir sus condenas en las duras condiciones de galeotes, se trataba de una medida que pronto se generalizó para comprender por igual a todos los habitantes del país cuyos delitos parecieron a los monarcas suficientemente graves como para merecer este castigo. Si tomamos en cuenta el corto, pero sustancioso, estudio de I.A.A. Thompson, 158 personas $^{47}$ de esta etnia aparecen incorporadas entre $1586-95$ a las galeras reales, lo que representa un 2,9 por cien del total. Un 75 por cien de estos gitanos procedía de Castilla, y sólo el 18 por cien habían sido presos por los alcaldes de Aragón, Granada y Valencia. Desde mi punto de vista, estas diferencias geográficas pueden ser consideradas ya desde estas fechas como característica de las diferentes circunstancias que pueden apreciarse en el seno de la minoría.

A pesar de esta necesidad de mano de obra barata, y de la eficacia con que hemos visto aplicar a las justicias las órdenes recibidas en tiempos de Felipe II, las dificultades administrativas y burocráticas propias de la época determinaron con cierta frecuencia que estos hombres quedaran hacinados en las cárceles sin que se terminara de tomar una decisión respecto a ellos. Evidentemente, estas circunstancias aumentaban sus sufrimientos y determinaban que la decisión de la Corona, además de cruel, resultara ineficaz. El alcalde de Málaga se lamentaba de una situación similar en 1581:

"La carcel de esta ciudad está tan llena de forçados que han acudido de todas partes que ya no caben porque son más de 200 y cada dia ban llegando y no ay prisiones con que tenellos, y an intentado de romper la

47 Thompson, IAA, "A Map of Crime in Sixteen-Century", en Economic History Review, n, 21, 1968, págs. 244-67. 
carcel para huyrse. Una noche les halle començado un agujero en una pared que si se tardara en allegar una ora más se se escaparan porque la carcel en que están es muy rruyn y de mal edificio de tapia. Suplica al rey envie algún navio para tomarlos" ${ }^{48}$.

Los condenados, como es lógico, no aceptaban mansamente su triste situación, y hacian todo lo posible para librarse de ella, cumpliendo, por otra parte, con la obligación de todo hombre privado de libertad de intentar recuperarla. Aunque los datos a este respecto no son tan abundantes como los hechos que acabamos de revisar de vez en cuando resulta posible recoger alguna escena de protesta como la que se describe en la siguiente carta de 1545:

«Haviendo suplicado a V.A. a los dias pasados ciertas egipcianas, fuera servido mandar soltar los egipcianos que estavan presos en la Galizabra San Ginés de que es tenedor el capitán Martín de Pedrola. V.M. dió cédula para que el dicho capitán havida ynfomaçlión de que los susodichos eran sus maridos los diese libertad con que dentro de IX dias se abecindasen en cualquier parte destos rreinos y no los cumpliendo y tomándolos fuessen bueltos a servir en las dichas Galizabra y quando la dicha cédula se notificó al dicho capitán. los egicianos havian hecho el delito siguiente. lo qual paresce ser asi por información de sietet testigos que presenta el dicho capitán. $Y$ es que estando la dicha Galizabra surta en el Puerto de la Villa de Santa Maria del puerto a XIIII del pasado mes de mayo, doscientos soldados que en ella avia con el aguazil se despidieron. $Y$ saliendo aquel dia el dicho capitan a buscar otros a la dicha villa y dexando a la guarda de la Galizabra tres soldados. estando cenando a las IIII oras de la tarde entre los XIIII egipcianos se rebolvio ciero rruido maliciosamente y yendo los dichos soldados a poner paz al primero una cuerda corrediça al pescueço y a los otros dos maltrataron como llegaron a ellos sin armas. $Y$ una muger que en la dicha Galizabra estaba, con un cuchillo corto la cuerda del dicho soldado y él y ella a tres de los dichos egipcianos haciendo que cesase la questión maliciosa, durante la qual dos ladrones que con ellos andavan al remo se desferraron y lo mesmo ocho de los dichos egipcianos y ante lo qual la dicha muger y el soldado se pusiesen al paso de la escala los VII dellos y un ladrón estaban ya en un batel y dando largo pensando alçancarle el otro le dió por temor que no fuesen maltratados se hecho a nadar y a se ahogó. $E$ dize que fue el primero se desferró. $Y$ así mesmo se echó a nadar otro gitano que no pudo alcançar la barca y fue luego tomado saliendo a tierra. $Y$ el dicho capitán sabido este subceso dió aviso a los lugares comarcanos, y que fuesen tras ellos y los hizieron con toda diligencia pero no an sido tomados asta agora. Que V. Alt. provea en esto y en el soltar a los que quedan $\mathrm{g}$ tres dellos herido y lo que sea servido pues que tal desacato cometieron ${ }^{49}$. 
De acuerdo con el documento que acabamos de ver, los galeotes $-y$ los gitanos entre ellos- podían recibir medidas de gracia que adelantasen su libertad, aunque tal vez, como en el caso anterior, llegaran cuando la desesperación les había empujado demasiado lejos. La situación en las cárceles inquisitoriales, a pesar de las opiniones de algunos autores, tampoco eran demasiado buena. Las noticias de que disponemos a este respecto son escasas, pero todo parece indicar que en muchas ocasiones resultaba preferible cumplir el tiempo de galeras que se estipulaba en las condenas antes de permanecer en la cárcel tanto real como inquisitorial... Por lo que se refiere a este aspecto, casi todos los documentos señalan que los presos pasaban hambre y dificultades materiales que aliviaban mendigando por las calles o vendiendo mercancías a un costo inferior al de los establecimientos oficiales, lo que originaba recelos y titigios ${ }^{50}$. El hacinamiento y el hambre, según podremos observar más adelante, causaba a veces más muertes que cumplir el servicio forzado del remo.

Afortunadamente, las circunstancias no fueron siempre tan adversas. De acuerdo con nuestras noticias, al menos en una ocasión durante el reinado de Felipe II la clemencia del rey pudo beneficiar a los condenados.

Según una cédula de 25 de febrero y 11 de agosto de $1573^{51}$ se volvió a escribir a las justicias para que se enviaran a todos los gitanos útiles para el remo a las reales galeras. Un año después, el rey escribió al marqués de Santa Cruz para pedirle la relación de los que todavía seguían cumpliendo esta pena. Los gitanos detenidos preocupaban al monarca, y con este motivo se intercambiaron notas entre el rey y el Marques de Santa Cruz que son una buena prueba del escrupuloso cuidado con que Felipe II actuaba en todo aquello que se refería a las cuestiones públicas. En la nota que se ha conservado respecto a este punto, pueden leerse los detalles acerca de estos hombres:

"... quando el Sr. D. Juan - de Austria - fue la primera vez a Levante como abía falta de gente en las galeras para el remo, se acordó se llevase a ellos todos los gitanos que anduvieran bagando por el reyno y así se hizo. $Y$ por su parte se a pedido que pues se echaron sin culpa y que otros que andan en ella an cumplido las condenaciones que fueron condenados, se les mandase dar libertad y para entender lo que son y las causas porque se hecharon y si los condenados an cumplido se acordó

so Sobre la situación de los presos en las cárceles del Santo Oficio puede verse mi artículo "La situación de los presos en las cárceles del Santo Oficio de Granada", en Espacio, Tiempo y Forma. (Homenaje a D. Antonio Béthencourt Massieu), págs. 669-685.

${ }_{51}$ AGS. Guerra Antigua, leg. 88, n. 359. 
se embiase esta relación para que vista en se proveyese lo que conbengaws 52 .

Los propios gitanos, por tanto, se habian dirigido a Felipe II para pedir su libertad, y es también el monarca quien se ocupa, del caso, al parecer, a pesar de los graves momentos por los que atravesaba la Corona. El Marqués de Santa Cruz comunicó que en las galeras había 59 gitanos, 27 de los cuales estaban condenados a seis años al remo desde el mes de abril de $1573^{53}$. Es decir, un años antes de que tuviese lugar este cruce de noticias. Los restantes habian sido entregados sin que se especificara el tiempo que habían de cumplir, puesto que se les apresó de acuerdo con las cédulas mencionadas.

El rey concedió la libertad a estos gitanos, aunque en el documento se especifica al margen que se les volverá a enviar a galeras si reinciden en sus delitos ${ }^{54}$.

El reinado de Felipe II fue, según vamos viendo, el periodo durante el cual la Corona tuvo más necesidad de reclutar hombres para el mar, especialmente para las empresas de don Juan de Austria, pero no terminan con este monarca las tribulaciones de los gitanos y restantes reos que cumplieron penas de galeras, puesto que también a lo largo del siglo XVII menudean las noticias a este respecto. Por los menos en cuatro ocasiones ${ }^{55}$, Felipe IV recurrió también a las mismas medidas que su abuelo para reunir galeotes, aunque no siempre las disposiciones que se dictaron al respecto sirvieron para reunir el número de brazos que requería el servicio de la guerra. Por una parte, Felipe IV dicta el 13 de octubre nuevas disposiciones que pretenden impedir los indultos y excepciones, renovando la prohibición. Por otra, y de acuerdo con la real cédula de diciembre de $1638^{56}$ se disponía que don Pedro de Amezquita, sería el hombre apropiado para ocuparse del problema. En la práctica no parece, sin embargo, que la actuación de los monarcas o de las justicias fuera siempre tan severa como hace suponer este decreto.

En junio de $1637^{57}$ tenemos noticias de las dificultades que experimentaba Pedro de Amezquita. Después de un decreto del propio rey que

AGS. Guerra antigua, leg. 87, n. 359.

AGS. Ibidem.

AGS. Ibidem.

55 DOMINGo ORtiz, Antonio, alude a estas levas en su breve pero ínestimable artículo *La esclavitud en Castilla durante la Edad Moderna" (Patronato de Historia Social de España del Instituto «Balmes» de Sociologia. Madrid, C.S.I.C., 1952, págs. 1 a 62.

56 AHN. Consejos, leg. 7.155

57 AHN. Consejos, Ibidem. 
había indultado a muchos de estos infelices, hara reclutar los galeotes necesarios para los navíos reales, a causa de las apelaciones e indultos y retrasos que impedian reunir los condenados que convenía destinar a este servicio. La deliberación del Consejo de Castilla a este respecto demuestra el estado de confusión a que daban lugar las apelaciones, y la diversidad de las medidas jurídicas conducentes a la leva de galeotes:

«En el Consejo se ha visto un decreto de V. Magestad del tenor siguiente: Haviendome consultado el Consejo de guerra que el alcalde Amezquita habia avissado por allí que en Toledo havia muy pocos galeotes por no haver llegado las cadenas de Valladolid y Soria y que en los demas lugares no havia hallado ninguno, porque los del donatibo los indultaban y que las causas de algunos sentenciados por las justicias ordinarias en primera instancia estavan sus causas sentenciados por las justicias ordinarias en primera instancia estavan sus causas en apelación en Granada y que de los rematados en Sevilla havia soltado don Gaspar de Bracamaonte veiinte. He yo atendido a lo mucho que importa proveer de forçados a las galeras he resuelto de mandar que se execute lo que tengo ordenado precissa e indispensablemente, y ordenareis a los que indultaron que buelvan a poner de manifiesto a los dichos forçados y assi se lo escrivireis luego y que las apelaciones de las justicias ordinarias es mi voluntad que se remitan al alcalde para atajar las dilaciones que ay en las Chancillerias en la determinación destas causas en lo qual dareis tambien las ordenes convenientes luego" ${ }^{58}$.

El Consejo estima, en vista de la falta de hombres para este trabajo, que es preciso actuar con prudencia por lo que se refiere a los indultos y dispone que se comunique a todos los que han intervenido en el derecho de las apelaciones e indultos de forzados «cumplan con satisfacción entera lo que $V$. Majestad ha sido servido de mandar en lo que toca a los forçados rematados que huvieren indultado en conformidad del real decreto, que en los que no estavan sino condenados solamente por las justicias ordinarias sujeta su condenación a rebocarse por los tribunales y audiençias a quien pertenesce su conocimiento en apelación o por ellos en vista no milita la misma raçon pues puede haver mobido la poca justificación de la causa al que le indultó, que para este efecto la ven antes, junto con acudir al servicio de $\mathrm{V}$. Magestad con cantidad de maravedis proporcionada al casso a que le concediesen, que no corre igualmente en los rematados por $V$. Magestad se lo manda se execute su real decreto como se hace» ${ }^{59}$. De acuerdo con la urgencia de la situación, se determina que en adelante se remitan estas causas al alcalde D. Pedro de

58 AHN. Consejos, Ibidem.

s9 Ibidem. 
Amezquita «para que conozca dellas, por hallar el Consejo conocidos reparos e inconbenientes le parece de su obligación representarlos a $\mathrm{V}$. Magestad para que destos mande lo que mas fuere servido" ${ }^{60}$.

El Consejo sigue deliberando acerca de lo que resulta conveniente respecto a las causas civiles y criminales "que tocan a la honra", respecto a las que recomienda ${ }^{61}$ y termina aconsejando que las causas se despachen con la mayor brevedad posible. Al parecer las dificultades para reunir galeotes eran tan grandes que Amezquita había recibido también la orden de reclutar esta mano de obra entre los esclavos de Andalucía, donde eran particularmente abundantes como servidores domésticos ${ }^{62}$. El 25 de agosto de $1637^{63}$ el Consejo volvía a informar sobre los obstáculos que presentaba una misión que perjudicaba especialmente a las familias propietarias de estos hombres que, indudablemente, no estaban acostumbrados a trabajos tan duros. Según el memorial que recibió el Consejo, la mayor parte de ellos, especialmente los cristianos, «trabajaban para sustentar a sus amos" muchos de los cuales eran pobres, viudas, o personas principales y honrradas que no tienen otra cossa de que vivir sino de lo que por medio de elllos adquieren y negocian cossa muy ussada en aquesta tierra y que sino oubiesse en ella esta gente que acudiesse a estos ministerios y que sirbiesse no ay otra que lo pueda hazer". Los propios miembros del Consejo se sienten inclinados a pedir clemencia al rey para amos y esclavos. Para los esclavos, porque están presos y hacinados, y la situación es tan grave que se teme que pueda dar lugar a algún contagio. En el caso de los amos porque «andan llorando publicamente por las calles llebados del dolor de verse sin sus esclavos en que consistía parte de su hazienda y en algunos toda, el sustento de sus familias y casa». La situación de los detenidos por otra parte, inclina al Consejo a consideraciones relacionadas con su fe cristiana que aconsejan también su libertad: "y que juntamente se teme que los esclavos como gente de tan pocas obligaciones con la impaciencia de berse llebar a galeras sin delito suyo se abenture a la fee que es en lo que mas debe repararse». Las dificultades de Felipe IV para reunir galeotes le obligan a comisionar de nuevo en diciembre de 1638 a Pedro de Amezquita ${ }^{64}$ para que se ocupe del asunto mediante un decreto en el que se observan las mismas complicaciones de carácter jurídico que en el caso anterior:

\footnotetext{
60 Ibidem.

Ibidem

62 Dominguez Ortiz, A., Art. cit. sup.

63 AHN. Consejos. leg. 7.155.

${ }_{64} \mathrm{AHN}$. Consejos, leg. 7,155.
} 
«El Consejo tiene entendido el cuidado y solicitud con que procuran por todos los medios que son posibles a acrecentar galeotes de las galeras y la importancia del efecto desto, supuesto lo qual, por haverse entendido que ay en las Chancilleria muchos pleitos pendientes de sentenciados a galeras, He resuelto que por el Consejo se escriva a los governadores de las Audiencias de Valladolid y Granada y Regente de Sevilla que dentro de cinquenta dias se vean que sentencian en todas instancias los pleitos de los que están conducidos a galeras, o lo pueden ser, no perdiendo ora de tiempo aunque sean vacaciones y que cada ocho dias os den aviso a vos el Arzobispo Governador de que ello resultaren, los quales entregareis al Secretario de la Junta, donde se tratará de materias de los galeotes. Asimismo, He resuelto que salgan personas de satisfacción por el reino y reconozcan los pleitos de los que estuvieren sentenciados en vista de galeras y determinen si se pueden executar las sentencias sin embargo de apelación y en las que se pudieren hacerles executar y las que no las las remitran a las Chancillerias para que las causas se fenezcan y las condenaciones de muerte en que no aya parte las puedan conmutar en galeras y quitar los azotes y verguenca dejando las condenaciones de galeras y que sin embargo las partes puedan seguir sus apelaciones aunque sean entregados a las galeras y se guarde 10 que por la ultima sentencia se determinare" ${ }^{65}$.

En 1640 todavía se continuaban disctando órdenes para conseguir reunir galeotes, lo que viene a confirmar la necesidad de esta mano de obra, y las dificultades con que se tropezaba a la hora de hacer cumplir las medidas:

«14 de marzo de 1640. He entendido que aunque en ejecución de lo que tengo mandado al Consejo se curan por el órdenes muy apretadas para que todos los sentenciados a galeras se revistan asi en esta corte y villa como en Valladolid, Granada y Sevilla, se llevasen luego a las cajas para conducirlos con los demás galeotes al Puerto y que se avisase a todas las partes a mediado este mes de marzo lo que uviese licenciado y que estado tiene la conduccion; no camina esto con la celeridad que insta la necesidad que hay de chusma para las galeras y assi he resuelto que de nuevo se envien más apretadas órdenes a los gobernadores de las dichas Chancillerias y Regente de Sevilla para que ejecuten lo que está ordenado con suma brevedad, y lo mismo se haga en esta Corte y villa, de manera que para fin de este mes estén en Cartagena todos los galeotes de las cajas de sus distritos y vandos en cavalgaduras y culparlos al no haber respondido lo que en esto se les ha ordenado. también ordenareis al Corregidor de Toledo que parta la cadena de allí luego, pues ha avisado que hay 37 galeotes rematados y porque los comisarios 
que salieron por el sy a lo tocante a galeotes no han cumplido con la orden de enviar relación cada 4 dias» ${ }^{66}$.

El 30 de marzo de $1640^{67}$ se reiteraban las órdenes solicitando que los comisarios y oidores enviaran a los condenados a la costa con la mayor brevedad posible sin que tengamos noticias exactas de cuántos galeotes fueron recogidos en total, y cuántos gitanos habia entre ellos. De acuerdo con una carta de 16 de marzo de $1640{ }^{68}$, en las cárceles de Toledo había 40 forzados que esperaban a ser enviados sin que hubiera dinero para hacerlo. Sin embargo, mejor que gracias a través de cualquier testimonio literario llegan los lamentos de estos infelices gracias de los memoriales presentados por los propios interesados tanto al tribunal del Santo Oficio como a los representantes de la justicia real. En julio de 1607 dirigía Domingo López el siguiente escrito a los inquisidores en un intento desesperado por conseguir su libertad:

«Domingo Lopez portugués sentenciado por tres años de galeras por los señores inquisidores de esta ciudad del Santo Oficio preso en la carzel pública de esta ciudad de Cordova digo a vuestras señorías que yo aqui estoi poreso en esta dicha carcel beinteiseis meses sin aver orden de llevarme a cunplir mi sentencia estoi enfermo padeciendo muchas necesidades desnudo y descalço sin remedio sino de Dios cargado de jierro $y$ con mil trabaxos.

Pido y suplico a vuestras señorias como misericorsiosos que son pues soi honbre maio de edad de cinquenta años antes mas si que no menos y con mi muxer la primera muerta y con tres hijas donçellas sin remedio un diez y siete años y otra de treze y la otra de seis años que esto que e estado preso se me desquente de mi penitencia o trabaxo a servir en concierto o espital porque como soi viejo como tengo dicho estoi sin vigor de poder llevar tanto trabaxo como el servir en galera. Haran vuestras señorias servicio a dios y a mi caridad para que yo pueda remediar mis hijas $(\ldots)^{69}$.

La actitud de los inquisidores no fue siempre, sin embargo, totalmente implacable. En 1740 exponía su caso Matías Montoya quien habia sido condenado a galeras. Explicaba que se encontraba enfermo del pecho, por lo que solicitaba se le conmutara esta pena. Después de someter el caso a la revisión de un médico los inquisidores dispusieron que no había inconveniente en sustituir este castigo por el de diez años de destierro ${ }^{70}$.

AHN. Inq. leg. 2.679 
En noviembre de 1682 tenemos noticias de dos gitanos que se dirigieron al rey para suplicarle que conmutara sus penas de galeras por la del trabajo forzado en las minas de Almadén.

Sebastián y Manuel Abendaño eran naturales de Aranda de Duero, y estaban presos en la cárcel de Palencia, desde donde enviaron un memorial en noviembre de 1681 solicitando la conmutación de su pena. En el memorial referían que habían sido condenados a seis años de galeras a causa del proceso que formó contra ellos el corregidor de Palencia en la Chancillería de Valladolid por decir que eran gitanos y hablar la lengua jerigonza. Suplicaban que se les diese permiso para cumplir la condena en las minas de Almadén, donde, por lo menos, no se verían privados del consuelo de sus mujeres e hijos, y del socorro que ellos les pudieran dar. Afortunadamente para nuestros condenados, el Consejo estimó que se le podía conceder la merced. En este caso, nuestros gitanos pudieron escapar de esta horrible pena.

Al margen de estos casos más o menos aislados, la suerte de los condenados a galeras era seguramente la peor del pais, según parece desprenderse también de la siguiente carta a propósito de los detenidos por el Santo Oficio:

«Nosotros, Bartolomé Moriana, Francisco Hidalgo, Juan Diulloca y los demás presos por la santa Inquisición, hablando con el devido respeto que se requiere decimos que aciendo seis meses que estamos aquí en esta cárzel pública padeciendo muchas y graves necesidades... Pedimos y suplicamos a vuestras señorias que se nos dé algún remedio para salir de aquí de este ynfierno para pagar nuestras culpas pues a tanto tiempo que padecemos tantos trabaxos según arriba ba referido que en ello harán vuestras señorías servicio a dios y a nosotros caridad y limosna” ${ }^{71}$.

Los presos que firmaban este escrito en la cárcel pública el año 1607 llevaban tanto tiempo esperando a que se les enviara a cumplir sus condenas que según un testimonio del propio tribunal, muchos habían muerto ya a causa de sus necesidades en la prisión, y los propios funcionarios señalaron a la Suprema que sería mejor enviarles a las galeras antes que manternerlos en la cárcel soportando los sufrimientos a que estaban sujetos. Estas noticias parecen confirmar los datos a que aludí anteriormente acerca de los terribles padecimientos de los condenados que permanecian en la cárcel esperando su juicio o el destino decidido en la sentencia.

1 AHN. Inq. leg. 2.679. 
Entre los condenados que firmaban este escrito en Córdoba no había ningún gitano, puesto que pocas veces cayeron en las manos de los inquisidores por delitos que pudieran merecer la pena, pero ya hemos visto con cuanta frecuencia, sin embargo, fueron comprendidos en las medidas que se dictaron con este motivo durante los siglos XVI y XVII.

En cualquier caso los sufrimiemtos que conllevaban la pena de galeras, parece que fueron tan temidos como la propia pena de muerte. El 5 de enero de 1647 Francisco Martínez de Mata - «siervo de los pobres afligidos"- conseguía mediante la presentación de un memorial al rey que se les devolviese la libertad a un grupo de forzados que ya habían cumplido su servicio en la galeras reales. Los términos en que se expresa este hombre entregado, al parecer, al ejercicio de la caridad con los penados, sitúan mejor al lector que cualquier otro testimonio ante las penalidades de los miles de desgraciados que fueron a dar con sus huesos en las cárceles del Antiguo Régimen y “mejoraron" a continuación su suerte contribuyendo con su esfuerzo a las empresas bélicas del país, tanto en España como en los navíos de las restantes potencias europeas de la época:

«Señor Francisco Martínez de Mata, natural de Motril, siervo de los Pobres afligidos. Digo, que por merced que Dios me ha hecho, tengo vocasión y exercicio de acudir a el consuelo y remedio de Pobres de Cárcel y Forçados de Galeras, y en ellas, he visto cosas tan lastimosas, que me han obligado a venir a mi costa, a representarlas a v. Magestad, y pedir su remedio. $Y$ es Señor, que no se cumple lo que vuestra $\mathrm{Ma}$ gestad manda, en las sentencias de sus Juezes: porque entrando los Forçados, por limitado tiempo, no se les da la soltura en cumpliendo y aunque, antes ay muchos que despues de aver cumplido, passan muy largo tiempo, como son 2, 4, 6, 8 años y de alguno tuve noticia, avía dies años que avia cumplido y aunque estos piden su libertad, como de justicia se les deve, no son oydos sus clamores, de que resultan gravísimos daños, como son las blasfemias y maldiciones que contra sí mesmos y contra quien assi los detiene, pronuncian desesperadamente, y las enfermedades, y assidentes de muerte en que muchos causa el verse tan agraviados de los mesmos Christianos que professan Ley que no permite agravios y no sólo en estos que han cumplido y se ven detenidos, haze suerte la desesperación, sino en los que de nuevo entran porque viendo este agravio, que passa en común le aprehenden sin remedio, y desesperan de su libertad, y aumentada esta pena la de su castigo, causa en muchos enfermedades de muerte, que ay algunos que no quieren recevir los Sacramentos ni aun para morir, cosa que por evitarla, se mando por decreto de vuestra Magestad, que ningun Forçado se le diese mas de diez años de Galeras, esto Señor, demas de que consume muchos Forçados, que mueren con riesgo de sus almas, es enperjuyzio y descredito de los Ministros superiores, que deven mantenernos en justicia; y pues a ninguno puede negarsele la justicia que tiene, no sean ellos Pobres danificados, valgales el aver cumplido sus penitencias, y no permita $V$. 
Los gitanos españoles desde su salida de la India hasta los primeros conflictos...

Magestad que la defensa de la $\mathrm{Fe}$ sea a fuerça de agravios, pues es cierto no se dará a Dios por servido, ni ayudará con buenos sucessos..." ${ }^{72}$

No resulta extraño, por consiguiente, que un gitano prefiriera convertirse en el verdugo de la villa de Madrid, a cambio de no cumplir su condena atado al remo.

De acuerdo con la documentación estudiada por R. Pike entre 1612 y 1668 sirvieron en las galeras reales un total de hombres ${ }^{73}$. Si tenemos en cuenta que los reos destinados a este castigo tenían el variado origen que ya vimos - moriscos, esclavos, etc. - no resulta aventurado señalar que el porcentaje de gitanos que contribuyeron a engrosar estos desgraciados fue bastante escaso. Por lo que se refiere a las galeras del Santo Oficio sólo unos cuantos gitanos aparecen condenados a este terrible destino ${ }^{74}$. Las referencias respecto a los que fueron enviados a galeras por las justicias reales son esporádicas y, si exceptuamos el pequeño contingente de individuos de esta etnia que sirvieron en las galeras de don Juan de Austria, el resto de los casos sólo hablan de tres o cuatro gitanos, según hemos visto. Así pues, aunque las penas a este respecto dictadas contra los gitanos resultan bastante duras desde el punto de vista legislativo, la consulta detallada de la documentación que se ha conservado al respecto parece indicar que, al igual que ocurrió con el decreto a propósito del destierro o la esclavitud, los gitanos consiguieron librarse con bastante frecuencia de tan triste suerte o la padecieron de forma similar a la de los infortunados que cayeron en las redes de la justicia real o del Santo Oficio.

72 Biblioteca Nacional (Madrid).

${ }_{33}$ PIKE, Ruth, Penal servitude in early Modern Spain, Univ. of Wiscosin Press, 1983.

74 Cf. SÁnchez Ortega, María-Helena, La Inquisición y los gitanos. Madrid, Taurus, 1987. 